\title{
PENERAPAN METODE ELECTRE UNTUK MENENTUKAN PRIORITAS PENERIMA BERAS MISKIN (RASKIN)
}

\author{
Yosi, Shantika Martha, Nurfitri Imro'ah
}

\begin{abstract}
INTISARI
ELECTRE adalah suatu metode yang dirancang untuk memecahkan masalah dari setiap alternatif yang memiliki lebih dari satu kriteria. Data yang digunakan dalam penelitian ini merupakan data calon penerima RASKIN di Desa X sebanyak 30 kepala keluarga. Alternatif yang digunakan adalah kepala keluarga dari setiap rumah, sedangkan kriterianya adalah usia, pekerjaan, penghasilan, luas bangunan tempat tinggal, jumlah tanggungan, tagihan listrik, dan konsumsi daging dalam seminggu. Berdasarkan analisis yang telah dilakukan terdapat 10 kepala keluarga yang mendapat rekomendasi untuk menerima RASKIN yaitu A14, A28, A29, A22, A12, A17, A8, A6, A9, dan A13.
\end{abstract}

Kata kunci: Alternatif, Kriteria, Kepala keluarga

\section{PENDAHULUAN}

Program bantuan sosial dari pemerintah dalam menangani kemiskinan dan menjaga pangan masyarakat berupa bantuan beras bagi yang kurang mampu dalam perekonomian, dikenal dengan istilah RASKIN (Beras Miskin). RASKIN adalah beras bersubsidi yang disalurkan oleh pemerintah, untuk meringankan beban masyarakat miskin dalam memenuhi kebutuhan pangan. Setiap daerah yang masuk ke dalam wilayah kesatuan Republik Indonesia berhak mendapatkan hak dan jatah yang sama dari program RASKIN [1]. Salah satu wilayah di Provinsi Kalimantan Barat yang juga mendapatkan hak bantuan RASKIN adalah penduduk warga desa X.

Minimnya jumlah anggota dari masyarakat yang dicantumkan untuk mendapatkan bantuan program RASKIN, menjadikan penyaluran bantuan program tersebut harus dikelola dengan baik. Hal ini dikarenakan masih banyak penyaluran yang belum tepat sasaran kepada masyarakat miskin. Oleh karena itu, perlu adanya sistem pendukung keputusan dalam menentukan penerima bantuan RASKIN. Dengan demikian hak masyarakat dapat tersalurkan dengan tepat. Sistem Pendukung Keputusan (SPK) bertujuan untuk menentukan tindakan yang lebih efektif [2]. Metode Elimination Et Choix Traduisant La Realite (ELECTRE) merupakan salah satu SPK yang digunakan untuk menentukan alternatif terbaik. Metode ELECTRE dapat membantu mengambil keputusan yang disusun dalam bentuk perankingan, dari setiap alternatif yang dipengaruhi banyaknya kriteria [3]. Dalam penelitian ini metode ELECTRE diterapkan untuk menentukan prioritas penerima RASKIN.

\section{ELIMINATION ET CHOIX TRADUISANT LA REALITE (ELECTRE)}

Metode ELECTRE merupakan metode yang peringkatannya dipengaruhi oleh banyaknya kriteria untuk setiap alternatif, menentukan keputusan, dan menyusun ranking alternatif terbaik. Sehingga metode ini sangat membantu pengambil keputusan dalam menentukan suatu kasus yang memiliki ketidakpastian dari suatu tindakan. ELECTRE digunakan pada kondisi dimana alternatif yang kurang sesuai dengan kriteria akan dieliminasi, dan alternatif yang sesuai dapat dihasilkan [4].

Kelebihan utama dari metode ELECTRE adalah metode ini mempermudah pengambil keputusan untuk menentukan keputusan dari ketidakjelasan dan ketidakpastian dalam sebuah kasus yang 
memiliki banyak alternatif. Langkah-langkah yang dilakukan dalam menggunakan ELECTRE diantaranya adalah sebagai berikut:

1. Normalisasi matriks keputusan

Setiap normalisasi $r_{i, j}$ dapat dilakukan dengan rumus sebagai berikut:

$$
r_{i, j}=\frac{x_{i, j}}{\sqrt{\sum_{i=1}^{m} x_{i, j}^{2}}}, \text { untuk } i=1,2,3, \ldots, m \text { dan } j=1,2,3, \ldots, n
$$

dengan $r_{i j}$ adalah normalisasi pengukuran pilihan dari alternatif ke- $i$ dalam hubungannya dengan kriteria ke- $j, x_{i, j}$ merupakan nilai rating setiap jawaban responden pada baris dan kolom, $m$ adalah jumlah alternatif, dan $n$ adalah jumlah kriteria. Sehingga didapat matriks $\mathbf{R}$ hasil normalisasi sebagai berikut:

$$
\boldsymbol{R}=\left[\begin{array}{cccc}
r_{1,1} & r_{1,2} & \cdots & r_{1, n} \\
r_{2,1} & r_{2,2} & \cdots & r_{2 n} \\
\vdots & \vdots & \ddots & \vdots \\
r_{m, 1} & r_{m, 2} & \cdots & r_{m, n}
\end{array}\right]
$$

2. Pembobotan pada matriks yang telah dinormalisasi

Matriks normalisasi terbobot (matriks V) adalah sebuah matriks yang merupakan hasil dari perhitungan matriks $r_{i, j}$ yang dikalikan dengan nilai bobot preferensi $\left(\mathrm{w}_{j}\right)$. Bobot preferensi ditentukan oleh pengambil keputusan berdasarkan hasil subjektif musyawarah antara perangkat desa dengan masyarakat. Nilai bobot merupakam nilai yang mengacu pada tingkat kepentingan suatu kriteria. Adapun proses perhitungan dapat dapat dilakukan pada persamaan berikut:

$$
v_{i, j}=r_{i, j} \cdot w_{j}
$$

Sehingga dapat dibentuk matriks normalisasi terbobot sebagai berikut:

$$
\boldsymbol{V}=\left[\begin{array}{cccc}
v_{1,1} & v_{1,2} & \ldots & v_{1, n} \\
v_{2,1} & v_{2,2} & \cdots & v_{2, n} \\
\vdots & \vdots & \ddots & \vdots \\
v_{m, 1} & v_{m, 2} & \cdots & v_{m, n}
\end{array}\right]
$$

Matriks $\mathbf{V}$ tersebut berguna untuk menentukan himpunan Concordance dan Discordance. Selain itu, Matriks $\mathbf{V}$ juga digunakan dalam menentukan matriks Discordance dengan mencari selisih maksimal dari elemen matriks $\mathbf{V}$ tersebut [5].

3. Penentuan himpunan Concordance dan Discordance

Setiap pasangan dari suatu alternatif $k$ dan $l(k, l=1,2,3, \ldots, m$ dan $k \neq 1)$ kumpulan kriteria $j$ dibagi menjadi dua subsets, yaitu himpunan Concordance dan Discordance. Sebuah kriteria dalam satu alternatif termasuk himpunan Concordance jika:

$$
C_{k, l}=\left\{j, v_{k, j} \geq v_{l j}\right\}, \text { untuk } j=1,2,3, \ldots, n
$$

Sebaliknya, apabila sebuah kriteria dalam satu alternatif termasuk himpunan Discordance jika:

$$
D_{k, l}=\left\{j, v_{k, j}<v_{l, j}\right\}, \text { untuk } j=1,2,3, \ldots, n
$$

Dengan $C_{k, l}, D_{k, l}, v_{k, j}$, dan $v_{l, j}$, berturut-turut adalah himpunan Concordance, himpunan Discordance, elemen dari matriks $\mathbf{V}$, dan elemen dari matriks $\mathbf{V}$.

4. Hitung matriks Concordance dan Discordance

Proses dalam menentukan nilai dari elemen-elemen pada matriks Concordance adalah dengan menjumlahkan bobot-bobot yang termasuk dalam subset Concordance, dengan menggunakan persamaan berikut:

$$
c_{k, l}=\sum_{j \in C_{k, l}} w_{j}
$$

Sehingga matriks Concordance yang dihasilkan adalah: 


$$
\boldsymbol{C}=\left[\begin{array}{ccccc}
- & c_{1,2} & c_{1,3} & \cdots & c_{1, n} \\
c_{2,1} & - & c_{2,3} & \cdots & c_{2, n} \\
\vdots & \vdots & \vdots & \ddots & \vdots \\
c_{m, 1} & c_{m, 2} & c_{m, 3} & \cdots & -
\end{array}\right]
$$

Sedangkan proses untuk menentukan setiap elemen-elemen pada matriks Discordance adalah dengan membagi maksimum selisih nilai kriteria yang termasuk dalam subset Discordance. Maksimum dari selisih nilai kriteria tersebut dibagi dengan maksimum selisih nilai seluruh kriteria yang ada. Secara matematis elemen pada matriks Discordance dihitung dengan persamaan (9) berikut:

$$
d_{k, l}=\frac{\max \left\{\left|v_{k, j}-v_{l, j}\right| ; j \in D_{k, l}\right\}}{\max \left\{\left|v_{k, j}-v_{l, j}\right| ; \text { setiap } j\right\}}
$$

Selanjutnya diperoleh matriks Discordance sebagai berikut:

$$
\boldsymbol{D}=\left[\begin{array}{ccccc}
- & d_{1,2} & d_{1,3} & \cdots & d_{1, n} \\
d_{2,1} & - & d_{2,3} & \cdots & d_{2, n} \\
\vdots & \vdots & \vdots & \ddots & \vdots \\
d_{m, 1} & d_{m, 2} & d_{m, 3} & \cdots & -
\end{array}\right]
$$

5. Penentuan matriks dominan Concordance dan Discordance

Matriks dominan Concordance (matriks F) dapat dibangun dengan bantuan nilai threshold, yaitu dengan membandingkan setiap nilai elemen matriks Concordance dengan nilai threshold.

$$
c_{k, l} \geq \underline{c}
$$

dengan nilai threshold $\underline{c}$, adalah:

$$
\underline{c}=\frac{\sum_{k=1}^{m} \sum_{l=1}^{m} C_{k, l}}{m(m-1)}
$$

dan setiap elemen matriks $\mathbf{F}$ sebagai matriks dominan Concordance ditentukan sebagai berikut:

$$
f_{k, l}=1, \text { jika } c_{k, l} \geq \underline{c} \text { dan } f_{k, l}=0 \text {, jika } c_{k, l}<\underline{c}
$$

Matriks dominan Discordance (matriks G) dapat dibangun menggunakan bantuan nilai threshold. Proses perhitungan untuk menentukan nilai threshold sebagai berikut:

$$
\underline{d}=\frac{\sum_{k=1}^{m} \sum_{l=1}^{m} d_{k, l}}{m(m-1)}
$$

dan setiap elemen untuk matriks $\boldsymbol{G}$ sebagai matriks dominan Discordance ditentukan sebagai berikut:

$$
g_{k, l}=0, \text { jika } d_{k, l} \geq \underline{d} \text { dan } g_{k, l}=1, j i k a d_{k, l}<\underline{d}
$$

6. Menentukan aggregate dominance matrix

Aggregate dominance matrix (matriks $\mathbf{E}$ ) merupakan perkalian antara elemen matriks $\mathbf{F}$ dengan elemen matriks $\mathbf{G}$ yang bersesuaian. Adapun proses perhitungan untuk menentukan elemen matriks $\mathbf{E}$ dapat dilakukan pada persamaan (16) berikut [3]:

7. Eliminasi alternatif yang less favourable.

$$
e_{k, l}=f_{k, l} \cdot g_{k, l}
$$

Eliminasi alternatif yang less favourable yaitu eliminasi berdasarkan hasil nilai matriks dominan agregat matriks E. Eliminasi matrik $\mathbf{E}$ merupakan elimiinasi yang dapat memberikan urutan pilihan dari setiap alternatif. Apabila nilai $e_{k, l}=1$ lebih banyak dari pada alternatif lainnya, maka alternatif tersebut yang akan dipilih untuk dilakukan perankingan. Sedangkan nilai $e_{k, l}=1$ yang paling sedikit akan dieliminasi.

\section{STUDI KASUS}

Data yang dianalisis dalam penelitian ini berupa data sekunder tahun 2018, yang diperoleh langsung dari Kantor Desa X. Data yang digunakan adalah data masyarakat calon penerima bantuan RASKIN sebanyak 30 kepala keluarga. Kriteria yang digunakan yaitu, usia (K1), jenis pekerjaan (K2), jumlah penghasilan perbulan (K3), luas bangunan tempat tinggal (K4), jumlah tanggungan (K5), biaya tagihan listrik perbulan (K6), dan konsumsi daging Sapi/ daging ayam perminggu (K7).

Analisis dimulai dengan menentukan tingkat kepentingan setiap kriteria (bobot preferensi). Bobot preferensi merupakan salah satu tolak ukur tingkat kepentingan suatu kriteria, dimana untuk 
mendapatkan tingkat kepentingan tersebut diperoleh berdasarkan hasil subjektif musyawarah antara perangkat desa dengan masyarakat. Hal ini dikarenakan situasi dan kondisi disetiap desa yang berbeda-beda. Sehingga untuk memperoleh nilai rating jawaban responden setiap alternatif pada kriterianya, diperoleh berdasarkan hasil wawancara fasilitator dengan calon penerima bantuan RASKIN. Nilai rating dari setiap jawaban responden mengacu pada bobot preferensi. Adapun bobot preferensi dan nilai rating setiap kriteria yang dimaksud dapat dilihat pada Tabel 1 sebagai berikut:

Tabel 1 Bobot Preferensi Pada Setiap Kriteria

\begin{tabular}{|c|c|c|c|c|c|}
\hline \multirow[b]{2}{*}{ Kriteria } & \multirow[b]{2}{*}{ Range } & \multicolumn{2}{|c|}{ Kuesioner } & \multicolumn{2}{|c|}{ Bobot } \\
\hline & & Jawaban & $\begin{array}{c}\text { Rating } \\
\text { Kriteria }\end{array}$ & $\begin{array}{c}\text { Bobot } \\
\text { Preferensi } \\
\text { (W) }\end{array}$ & $\begin{array}{c}\text { Skala } \\
\text { Prioritas }\end{array}$ \\
\hline \multirow{5}{*}{ Usia } & $\leq 30$ tahun & A & 1 & & \multirow{5}{*}{$\begin{array}{l}\text { Sangat } \\
\text { Tinggi }\end{array}$} \\
\hline & 30 tahun $\leq \mathrm{x}<40$ tahun & B & 2 & & \\
\hline & 40 tahun $\leq \mathrm{x}<50$ tahun & $\mathrm{C}$ & 3 & 5 & \\
\hline & 50 tahun $\leq \mathrm{x}<60$ tahun & $\mathrm{D}$ & 4 & & \\
\hline & $\geq 60$ tahun & $\mathrm{E}$ & 5 & & \\
\hline \multirow{5}{*}{ Pekerjaan } & PNS/TNI/POLISI & A & 1 & & \multirow{5}{*}{ Tinggi } \\
\hline & Pegawai Swasta & B & 2 & & \\
\hline & Buruh/Petani/Wiraswasta & $\mathrm{C}$ & 3 & 4 & \\
\hline & $\begin{array}{l}\text { Tenaga kerja kasar(Buruh } \\
\text { tani/ Buruh bangunan) }\end{array}$ & $\mathrm{D}$ & 4 & 4 & \\
\hline & Pengganguran/Tidak bekerja & $\mathrm{E}$ & 5 & & \\
\hline \multirow{5}{*}{$\begin{array}{l}\text { Penghasilan } \\
\text { Bulanan }\end{array}$} & $\geq$ Rp. 2.400 .000 & A & 1 & & \multirow{5}{*}{ Tinggi } \\
\hline & Rp. $1.800 .000-$ Rp. 2.400 .000 & B & 2 & & \\
\hline & Rp. 1.200.000-Rp. 1.800 .000 & $\mathrm{C}$ & 3 & 4 & \\
\hline & Rp. $600.000-$ Rp. 1.200 .000 & $\mathrm{D}$ & 4 & & \\
\hline & $\leq$ Rp. 600.000 & $\mathrm{E}$ & 5 & & \\
\hline \multirow{5}{*}{$\begin{array}{l}\text { Luas } \\
\text { Bangunan }\end{array}$} & $\geq 100 \mathrm{~m}^{2}$ & A & 1 & & \multirow{5}{*}{ Rendah } \\
\hline & $80 m^{2}-100 m^{2}$ & B & 2 & & \\
\hline & $60 m^{2}-80 m^{2}$ & $\mathrm{C}$ & 3 & 2 & \\
\hline & $40 m^{2}-60 m^{2}$ & $\mathrm{D}$ & 4 & & \\
\hline & $\leq 40 \mathrm{~m}^{2}$ & $\mathrm{E}$ & 5 & & \\
\hline \multirow{5}{*}{$\begin{array}{l}\text { Jumlah } \\
\text { Tanggungan }\end{array}$} & 0 (tidak ada anggota keluarga) & A & 1 & & \multirow{5}{*}{ Cukup } \\
\hline & 1 Orang & B & 2 & & \\
\hline & 2 Orang & $\mathrm{C}$ & 3 & 3 & \\
\hline & 3 Orang & $\mathrm{D}$ & 4 & & \\
\hline & $\geq 4$ Orang & $\mathrm{E}$ & 5 & & \\
\hline \multirow{5}{*}{$\begin{array}{l}\text { Tagihan } \\
\text { Listrik }\end{array}$} & $\geq$ Rp. 100.000 & A & 1 & & \multirow{5}{*}{ Tinggi } \\
\hline & Rp. $75.000-$ Rp. 100.000 & B & 2 & & \\
\hline & Rp. 50.000-Rp. 75.000 & $\mathrm{C}$ & 3 & 4 & \\
\hline & Rp. $25.00-$ Rp. 50.000 & $\mathrm{D}$ & 4 & & \\
\hline & $\leq$ Rp. 25.000 & E & 5 & & \\
\hline \multirow{5}{*}{$\begin{array}{l}\text { Konsumsi } \\
\text { Daging }\end{array}$} & $\geq 4$ kali & A & 1 & & \multirow{5}{*}{$\begin{array}{l}\text { Sangat } \\
\text { Rendah }\end{array}$} \\
\hline & 3 kali & B & 2 & & \\
\hline & 2 kali & $\mathrm{C}$ & 3 & 1 & \\
\hline & 1 kali & $\mathrm{D}$ & 4 & & \\
\hline & Tidak Ada & $\mathrm{E}$ & 5 & & \\
\hline
\end{tabular}

Usia memiliki bobot preferensi sebesar 5 yang artinya kriteria usia memiliki skala prioritas sangat tinggi, sehingga kriteria usia dinilai lebih penting dibandingkan dengan kriteria lainnya. Selanjutnya dapat dilakukan perangkuman data dari setiap nilai rating kriteria berdasarkan jawaban responden. 
Jika responden memilih jawaban A maka rating kriteria yang diperoleh adalah 1, apabila respnden memilih jawaban B maka rating kriteria yang diperoleh adalah 2 dan seterunya. Jika responden memilih jawaban E maka rating yang diperoleh adalah 5. Perangkuman data berisikan nilai rating kriteria diantaranya: 1 merupakan rating bernilai sangat tidak layak, 2 merupakan rating bernilai tidak layak, 3 merupakan rating bernilai cukup layak, 4 merupakan rating bernilai layak, dan 5 merupakan rating bernilai sangat layak. Untuk menyusun perangkuman nilai rating pada setiap alternatif kriteria, dapat ditentukan berdasarkan kecocokan kuisioner dengan data calon penerima RTS-PM RASKIN (Rumah Tangga Sasaran Penerima Manfaat Beras Miskin). Adapun hasil perangkuman nilai rating berdasarkan jawaban responden disetiap setiap alternatif pada kritria dapat dilihat pada Tabel 2 sebagai berikut:

Tabel 2 Hasil Rating Berdasarkan Jawaban Responden

\begin{tabular}{|c|c|c|c|c|c|c|c|}
\hline \multirow[b]{2}{*}{ Alternatif } & \multicolumn{7}{|c|}{ Kriteria } \\
\hline & Usia & Pekerjaan & $\begin{array}{c}\text { Penghasilan } \\
\text { Bulanan }\end{array}$ & $\begin{array}{c}\text { Luas } \\
\text { Bangunan }\end{array}$ & $\begin{array}{c}\text { Jumlah } \\
\text { Tanggungan }\end{array}$ & $\begin{array}{c}\text { Tagihan } \\
\text { Listrik }\end{array}$ & $\begin{array}{c}\text { Konsumsi } \\
\text { Daging }\end{array}$ \\
\hline $\mathrm{A} 1$ & 2 & 3 & 3 & 4 & 3 & 4 & 5 \\
\hline $\mathrm{A} 2$ & 3 & 3 & 2 & 4 & 5 & 2 & 3 \\
\hline A3 & 4 & 3 & 3 & 2 & 2 & 4 & 2 \\
\hline A4 & 3 & 3 & 4 & 3 & 4 & 3 & 5 \\
\hline A5 & 3 & 3 & 2 & 2 & 4 & 3 & 3 \\
\hline A6 & 4 & 4 & 3 & 3 & 4 & 3 & 4 \\
\hline A7 & 2 & 2 & 2 & 5 & 5 & 4 & 5 \\
\hline A8 & 3 & 3 & 3 & 4 & 5 & 4 & 4 \\
\hline A9 & 4 & 3 & 3 & 2 & 5 & 3 & 2 \\
\hline A 10 & 3 & 3 & 1 & 1 & 4 & 1 & 1 \\
\hline A11 & 3 & 3 & 3 & 2 & 5 & 2 & 3 \\
\hline A12 & 3 & 4 & 4 & 4 & 2 & 5 & 5 \\
\hline A13 & 3 & 4 & 3 & 4 & 4 & 3 & 4 \\
\hline A14 & 5 & 5 & 5 & 3 & 3 & 4 & 5 \\
\hline A15 & 3 & 3 & 1 & 2 & 4 & 1 & 2 \\
\hline A16 & 2 & 3 & 1 & 4 & 4 & 3 & 5 \\
\hline A17 & 4 & 3 & 4 & 3 & 3 & 4 & 5 \\
\hline A18 & 1 & 2 & 1 & 1 & 3 & 2 & 2 \\
\hline A19 & 4 & 3 & 3 & 3 & 3 & 2 & 3 \\
\hline $\mathrm{A} 20$ & 3 & 2 & 1 & 4 & 4 & 2 & 3 \\
\hline A 21 & 3 & 2 & 1 & 2 & 4 & 1 & 2 \\
\hline A 22 & 5 & 5 & 5 & 4 & 1 & 5 & 5 \\
\hline A 23 & 3 & 2 & 1 & 3 & 4 & 1 & 1 \\
\hline A24 & 2 & 2 & 1 & 1 & 3 & 2 & 3 \\
\hline A25 & 4 & 3 & 3 & 1 & 5 & 2 & 4 \\
\hline A26 & 3 & 2 & 2 & 1 & 3 & 1 & 3 \\
\hline A27 & 3 & 2 & 3 & 2 & 5 & 3 & 5 \\
\hline A 28 & 5 & 5 & 5 & 2 & 2 & 4 & 5 \\
\hline A 29 & 3 & 5 & 5 & 3 & 3 & 4 & 5 \\
\hline $\mathrm{A} 30$ & 4 & 2 & 1 & 1 & 5 & 1 & 1 \\
\hline
\end{tabular}

1. Perhitungan matriks normalisasi

Proses perhitungan untuk menentukan setiap elemen pada matriks normalisasi dapat dilakukan pada persamaan (1), adapun hasil dari perhitungan tersebut sebagai berikut: 


$$
\begin{aligned}
& r_{1,1}=\frac{2}{\sqrt{\left((2)^{2}+(3)^{2}+(4)^{2}+(3)^{2}+\ldots+(4)^{2}\right)}}=0,109 \\
& r_{2,1}=\frac{3}{\sqrt{\left((2)^{2}+(3)^{2}+(4)^{2}+(3)^{2}+\ldots+(4)^{2}\right)}}=0,163 \\
& \vdots \\
& r_{30,1}=\frac{4}{\sqrt{\left((2)^{2}+(3)^{2}+(4)^{2}+(3)^{2}+\ldots+(4)^{2}\right)}}=0,217
\end{aligned}
$$

Sehingga

2. Matriks normalisasi terbobot

$$
\mathbf{R}_{30,7}=\left[\begin{array}{cccc}
0,109 & 0,176 & \cdots & 0,243 \\
0,163 & 0,176 & \cdots & 0,146 \\
\vdots & \vdots & \ddots & \vdots \\
0,217 & 0,118 & \cdots & 0,146
\end{array}\right]
$$

Perhitungan matriks normalisasi terbobot diperoleh dengan cara mengalikan setiap elemen yang ada pada sebuah kriteria yang telah dinormalisasi (matriks $\mathbf{R}$ ) dengan bobot preferensi $(\mathbf{W})$ pada Tabel 1. Hasil perhitungan tersebut dapat dilakukan pada persamaan (3), maka:

$$
\begin{gathered}
\mathrm{v}_{1,1}=(0,109)(5)=0,543 \\
\mathrm{v}_{2,1}=(0,163)(5)=0,815 \\
\vdots \\
\mathrm{v}_{30,1}=(0,217)(5)=1,086
\end{gathered}
$$

Sehingga

\section{Himpunan Concordance}

$$
\mathbf{V}_{30,7}=\left[\begin{array}{cccc}
0,543 & 0,706 & \cdots & 0,243 \\
0,815 & 0,706 & \cdots & 0,146 \\
\vdots & \vdots & \ddots & \vdots \\
1,086 & 0,471 & \cdots & 0,049
\end{array}\right]
$$

Perhitungan himpunan Concordance dilakukan dengan menggunakan setiap elemen matriks $\mathbf{V}$. Proses ini dilakukan untuk memilah kriteria yang masuk dalam himpunan Concordance maupun Discordance. Perhitungan untuk memilah kriteria tersebut adalah dengan membandingkan setiap alternatif dalam sebuah kriteria menggunakan persamaan (5). Sehingga hasil perhitungan dapat diperoleh sebagai berikut:

$$
\begin{aligned}
& C_{1,2}=\left\{j=1, \mathrm{v}_{1,1} \text { dibandingkan dengan } \mathrm{v}_{2,1}\right\}=\{1 ; 0,543<0,815\} ; \text { untuk } j=\{0\} \\
& C_{1,2}=\left\{j=2, \mathrm{v}_{1,2} \text { dibandingkan dengan } \mathrm{v}_{2,2}\right\}=\{2 ; 0,706 \geq 0,706\} ; \text { untuk } j=\{2\} \\
& C_{1,2}=\left\{j=3, \mathrm{v}_{1,3} \text { dibandingkan dengan } \mathrm{v}_{2,3}\right\}=\{3 ; 0,740 \geq 0,493\} ; \text { untuk } j=\{3\} \\
& C_{1,2}=\left\{j=4, \mathrm{v}_{1,4} \text { dibandingkan dengan } \mathrm{v}_{2,4}\right\}=\{4 ; 0,502 \geq 0,502\} ; \text { untuk } j=\{4\} \\
& C_{1,2}=\left\{j=5, \mathrm{v}_{1,5} \text { dibandingkan dengan } \mathrm{v}_{2,5}\right\}=\{5 ; 0,427<0,711\} ; \text { untuk } j=\{0\} \\
& C_{1,2}=\left\{j=6, \mathrm{v}_{1,6} \text { dibandingkan dengan } \mathrm{v}_{2,6}\right\}=\{6 ; 0,965 \geq 0,482\} ; \text { untuk } j=\{6\} \\
& C_{1,2}=\left\{j=7, \mathrm{v}_{1,7} \text { dibandingkan dengan } \mathrm{v}_{2,7}\right\}=\{7 ; 0,243 \geq 0,146\} ; \text { untuk } j=\{7\}
\end{aligned}
$$

Dari perhitungan himpunan Concordance, $\{0\}$ menyatakan bahwa suatu kriteria tidak dimasukan kedalam himpunan Concordance, akan tetapi kriteria tersebut masuk kedalam himpunan Discordance. Sehingga hasil penentuan himpunan Concordance diperoleh sebagai berikut:

$$
\begin{aligned}
& C_{1,2}=\{2,3,4,6,7\} \\
& C_{2,1}=\{1,2,4,5\} \\
& \vdots \\
& C_{30,1}=\{1,5\}
\end{aligned}
$$




\section{Matriks Concordance}

Setelah mengetahui kriteria mana saja yang masuk ke himpunan Concordance, maka langkah selanjutnya adalah menghitung elemen-elemen pada matriks Concordance. Proses perhitungan diakukan dengan menjumlahkan nilai bobot preferensi yang termasuk dalam himpunan Concordance. Adapun langkah untuk menetukan setiap elemen matriks Concordance yaitu dengan menggunakan persamaan (7). Sehingga diperoleh hasil perhitungan sebagai berikut:

$$
\begin{aligned}
& c_{1,2}=4+4+2+4+1=15 \\
& c_{2,1}=5+4+2+3=14 \\
& \vdots \\
& c_{30,1}=5+3=8
\end{aligned}
$$

Dari hasil penjumlahan setiap bobot preferensi maka diperoleh sebuah matrik Concordance sebagai berikut:

\section{Nilai threshold pada Concordance}

$$
\mathbf{C}_{30,30}=\left[\begin{array}{cccc}
- & 15 & \cdots & 15 \\
14 & - & \cdots & 18 \\
\vdots & \vdots & \ddots & \vdots \\
8 & 8 & \cdots & -
\end{array}\right]
$$

Nilai threshold $(\underline{c})$ berfungsi sebagai nilai pembanding untuk mendapatkan nilai matriks dominan Concordance pada setiap baris dan kolom. Jika nilai pada matriks Concordance lebih besar atau sama dengan nilai threshold maka akan diberi nilai 1, jika lebih kecil maka akan diberi nilai 0 .

Diketahui nilai threshold $(\underline{c})$ :

$$
\underline{c}=\frac{\sum_{k=1}^{m} \sum_{l=1}^{m} c_{k, l}}{m(m-1)}=\frac{12543}{30(30-1)}=14,417
$$

Adapun hasil perbandingan dari matriks Concordance dengan nilai treshold adalah sebagai berikut [5]:

\section{Himpunan Discordance}

$$
\mathbf{F}_{30,30}=\left[\begin{array}{cccc}
- & 1 & \cdots & 1 \\
0 & - & \cdots & 1 \\
\vdots & \vdots & \ddots & \vdots \\
0 & 0 & \cdots & -
\end{array}\right]
$$

Perhitungan himpunan Discordance dilakukan dengan menggunakan setiap elemen matriks $\mathbf{V}$. Proses ini dilakukan untuk memilah kriteria yang masuk dalam himpunan Discordance. Perhitungan untuk memilah kriteria tersebut adalah dengan membandingkan setiap alternatif dalam sebuah kriteria menggunakan persamaan (6). Sehingga hasil perhitungan dapat diperoleh sebagai berikut:

$$
\begin{aligned}
& D_{1,2}=\left\{j=1, \mathrm{v}_{1,1} \text { dibandingkan dengan } \mathrm{v}_{2,1}\right\}=\{1,0,543<0,815\} ; \text { untuk } j=\{1\} \\
& D_{1,2}=\left\{j=2, \mathrm{v}_{1,2} \text { dibandingkan dengan } \mathrm{v}_{2,2}\right\}=\{2,0,706 \geq 0,706\} ; \text { untuk } j=\{0\} \\
& D_{1,2}=\left\{j=3, \mathrm{v}_{1,3} \text { dibandingkan dengan } \mathrm{v}_{2,3}\right\}=\{3,0,740 \geq 0,493\} ; \text { untuk } j=\{0\} \\
& D_{1,2}=\left\{j=4, \mathrm{v}_{1,4} \text { dibandingkan dengan } \mathrm{v}_{2,4}\right\}=\{4,0,502 \geq 0,502\} ; \text { untuk } j=\{0\} \\
& D_{1,2}=\left\{j=5, \mathrm{v}_{1,5} \text { dibandingkan dengan } \mathrm{v}_{2,5}\right\}=\{5,0427<0,711\} ; \text { untuk } j=\{5\} \\
& D_{1,2}=\left\{j=6, \mathrm{v}_{1,6} \text { dibandingkan dengan } \mathrm{v}_{2,6}\right\}=\{6,0,965 \geq 0,482\} ; \text { untuk } j=\{0\} \\
& D_{1,2}=\left\{j=7, \mathrm{v}_{1,7} \text { dibandingkan dengan } \mathrm{v}_{2,7}\right\}=\{7,0,243 \geq 0,146\} ; \text { untuk } j=\{0\}
\end{aligned}
$$

Dari perhitungan himpunan Discordance, $\{0\}$ menyatakan bahwa suatu kriteria tidak dimasukan kedalam himpunan Discordance, akan tetapi kriteria tersebut sudah masuk kedalam himpunan Concordance. Sehingga hasil penentuan himpunan Discordance diperoleh sebagai berikut:

$$
\begin{aligned}
& D_{1,2}=\{1,5\} \\
& D_{2,1}=\{3,6,7\}
\end{aligned}
$$




$$
D_{30,1}=\{2,3,4,6,7\}
$$

\section{Matriks Discordance}

Proses untuk menentukan setiap elemen-elemen pada matriks Discordance adalah dengan membagi nilai maksimum dari selisih kriteria yang termasuk ke dalam himpunan Discordance. Elemen matriks Discordance dapat ditentukan dari pengurangan dari elemen matriks V yang masuk ke dalam himpunan Discordance. Hasil perhitungan matriks Discordance adalah sebagai berikut:

$$
\begin{aligned}
& d_{1,2}=\frac{\max \left\{\left|v_{1,1}-v_{2,1}\right| ;\left|v_{1,5}-v_{2,5}\right| ; j \epsilon D_{k, l}\right\}}{\max \left\{\left|v_{1,1}-v_{2,1}\right| ;\left|v_{1,2}-v_{2,1}\right| ; \cdots ;\left|v_{1,7}-v_{2,7}\right| ; \text { setiap } j\right\}} \\
& d_{1,2}=\frac{\max \{|0,543-0,815| ;|0,427-0,711|\}}{\max \{|0,543-0,815| ;|0,706-0,706| ; \cdots ;|0,243-0,146|\}} \\
& d_{1,2}=\frac{\max \{0,284\}}{\max \{0,482\}}=0,590 \\
& d_{2,1}=\frac{\max \left\{\left|v_{2,3}-v_{1,3}\right| ;\left|v_{2,6}-v_{1,6}\right| ;\left|v_{2,7}-v_{1,7}\right| ; j \in D_{k, l}\right\}}{\max \left\{\left|v_{2,1} \mathbf{v}_{1,1}\right| ;\left|v_{2,2}{ }^{-} \mathrm{v}_{1,2}\right| ; \cdots ;\left|v_{2,7}-\mathrm{v}_{1,7}\right| ; \text { setiap } j\right\}} \\
& d_{2,1}=\frac{\max \{|0,493-0,740| ;|0,482-0,965| ;|0,146-0,243|\}}{\max \{|0,815-0,543| ;|0,706-0,706| ; \cdots ;|0,146-0,243|\}} \\
& d_{2,1}=\frac{\max \{0,482\}}{\max \{0,482\}}=1 \\
& \text { : } \\
& d_{30,1}=\frac{\max \left\{\left|v_{30,2}-v_{1,2}\right| ;\left|v_{30,3}-v_{1,3}\right| ;\left|v_{30,4}-v_{1,4}\right| ;\left|v_{30,6}-v_{1,6}\right| ;\left|v_{30,7}-v_{1,7}\right| ; j \in D_{k, l}\right\}}{\max \left\{\left|v_{30,1}-v_{2,1}\right| ;\left|; v_{30,2}-v_{1,2}\right| ; \cdots ; ;\left|v_{30,7}-v_{1,7}\right| ; \text { setiap } j\right\}} \\
& d_{30,1}=\frac{\max \{|0,471-0,706| ;|0,247-0,740| ;|0,125-0,502| ;|0,241-0,965| ;|0,049-0,243|\}}{\max \{|1,086-0,543| ;|0,471-0,706| ; \cdots ;|0,049-0,243|\}} \\
& d_{30,1}=\frac{\max \{0,724\}}{\max \{0,724\}}=1
\end{aligned}
$$

Demikian dan seterusnya, sehingga didapat matriks Discordance sebagai berikut:

\section{Nilai threshold pada Discordance}

$$
\mathbf{D}_{30,30}=\left[\begin{array}{cccc}
- & 0,590 & \cdots & 0,751 \\
1 & - & \cdots & 0,721 \\
\vdots & \vdots & \ddots & \vdots \\
1 & 1 & \cdots & -
\end{array}\right]
$$

Nilai threshold $(\underline{d})$ berfungsi sebagai nilai pembanding untuk mendapatkan nilai matriks dominan Discordance pada setiap baris dan kolom. Jika nilai pada matriks Discordance lebih kecil dari nilai threshold maka akan diberi nilai 1, jika lebih besar atau sama dengan maka akan diberi nilai 0 .

Diketahui:threshold $(\underline{d}): \underline{d}=\frac{\sum_{k=1}^{m} \sum_{l=1}^{m} d_{k, l}}{m(m-1)}=\frac{612,042}{30(30-1)}=0,7035$

Adapun hasil perbandingan tersebut dapat dilihat pada matriks $\mathrm{G}$ berikut [5]:

\section{Penentuan aggregate dominance matrix}

$$
\mathbf{G}_{30,30}=\left[\begin{array}{cccc}
- & 1 & \cdots & 0 \\
0 & - & \cdots & 0 \\
\vdots & \vdots & \ddots & \vdots \\
0 & 0 & \cdots & -
\end{array}\right]
$$

Aggregate dominan matriks merupakan hasil perkalian titik pada baris matriks $\mathbf{F}$ terhadap baris pada matriks G. Adapun hasil dari perkalian tersebut dapat dilihat sebagai berikut:

$$
\mathbf{F}_{30,30} \cdot \mathbf{G}_{30,30}=\left[\begin{array}{cccc}
- & 1 & \cdots & 1 \\
0 & - & \cdots & 1 \\
\vdots & \vdots & \ddots & \vdots \\
0 & 0 & \cdots & -
\end{array}\right] \cdot\left[\begin{array}{cccc}
- & 1 & \cdots & 0 \\
0 & - & \cdots & 0 \\
\vdots & \vdots & \ddots & \vdots \\
0 & 0 & \cdots & -
\end{array}\right]
$$

hasil dari perkalian titik matriks aggregate dinamakan matriks $\mathbf{E}$, sehingga: 
10. Penentuan eliminasi alternatif

$$
\mathbf{E}_{30,30}=\left[\begin{array}{cccc}
- & 1 & \cdots & 0 \\
0 & - & \cdots & 0 \\
\vdots & \vdots & \ddots & \vdots \\
0 & 0 & \cdots & -
\end{array}\right]
$$

Dari hasil perhitungan matriks E, maka dapat diketahui urutan peringkat setiap alternatif. Apabila nilai $e_{k, l}=1$ lebih banyak dari pada alternatif lainnya, maka alternatif tersebut yang akan dipilih untuk dilakukan perankingan. Sedangkan nilai $e_{k, l}=1$ yang paling sedikit akan dieliminasi. Jika $e_{k, l}=1$ pada alternatif memiliki jumlah yang sama banyaknya pada setiap alternatif, maka perlu dilakukan perbandingan antara jumlah elemen yang sama pada matriks normalisasi terbobot. Dengan demikian, alternatif terbaik adalah alternatif yang mendominasi alternatif lainnya. Perankingan dilakukan dengan menjumlahkan setiap elemen matriks $\mathbf{V}$ yaitu $\mathrm{v}_{1,1}+\mathrm{v}_{1,2}+\mathrm{v}_{1,3}+\cdots+\mathrm{v}_{1, \mathrm{n}}$ hingga seterusnya pada masing-msing alternatif. hasil penjumlahan dari setip elemen matriks $\mathbf{V}$ yaitu $\mathrm{v}_{1,1}+\mathrm{v}_{1,2}+\mathrm{v}_{1,3}+\cdots+\mathrm{v}_{1, \mathrm{n}}$ tersebut dibagi dengan banyaknya jumlah kolom $j$ (kolom pada kriteria). Sehingga diperoleh nilai perbandingan alternatif peringkat terbaik. Pada penelitian ini salah satu alternatif memiliki nilai $e_{k, l}$ yang sama adalah A28 dan A29, untuk perhitungannya sebagai berikut:

$$
\begin{aligned}
& \text { A28 }=\frac{1,358+1,136+1,233+1,251+0,284+0,965+0,243}{7}=0,781 \\
& \text { A29 }=\frac{0,815+1,136+1,233+0,376+0,427+0,965+0,243}{7}=0,742
\end{aligned}
$$

Hasil perhitungan diperoleh alternatif yang lebih tinggi yaitu sebesar 0,781 pada alternatif A28. Perolehan perankingan dari 30 alternatif dapat dilihat pada Tabel 3 berikut:

Tabel 3 Hasil Perankingan Nilai $e_{k, l}=1$

\begin{tabular}{crrrrr}
\hline \multirow{2}{*}{ No } & \multicolumn{2}{c}{ Sebelum Perankingan } & \multicolumn{2}{c}{ Sesudah Perankingan } \\
\cline { 2 - 6 } & Alternatif & $\begin{array}{r}\text { Jumlah } \\
e_{k, l}=1\end{array}$ & Alternatif & $\begin{array}{r}\text { Jumlah } \\
e_{k, l}=1\end{array}$ & Rank \\
\hline 1 & A1 & 11 & A14 & 29 & 1 \\
2 & A2 & 8 & A28 & 23 & 2 \\
3 & A3 & 12 & A29 & 23 & 3 \\
4 & A4 & 14 & A6 & 19 & 6 \\
5 & A5 & 8 & A8 & 19 & 8 \\
6 & A6 & 19 & A12 & 19 & 5 \\
7 & A7 & 6 & A17 & 19 & 7 \\
8 & A8 & 19 & A22 & 19 & 4 \\
9 & A9 & 18 & A9 & 18 & 9 \\
10 & A10 & 2 & A13 & 14 & 10 \\
11 & A11 & 10 & A4 & 14 & 11 \\
12 & A12 & 19 & A3 & 12 & 12 \\
13 & A13 & 14 & A1 & 11 & 13 \\
14 & A14 & 29 & A25 & 10 & 14 \\
15 & A15 & 5 & A19 & 10 & 15 \\
16 & A16 & 6 & A27 & 10 & 16 \\
17 & A17 & 19 & A11 & 10 & 17 \\
18 & A18 & 0 & A2 & 8 & 18 \\
19 & A19 & 10 & A5 & 8 & 19 \\
20 & A20 & 6 & A7 & 6 & 20 \\
\hline
\end{tabular}




\begin{tabular}{rrrrrr}
21 & A21 & 1 & A16 & 6 & 21 \\
22 & A22 & 19 & A20 & 6 & 22 \\
23 & A23 & 2 & A15 & 5 & 23 \\
\hline & \multicolumn{2}{c}{ Sebelum Perankingan } & & \multicolumn{2}{c}{ Sesudah Perankingan } \\
\cline { 2 - 6 } No & \multirow{2}{*}{ Alternatif } & Jumlah & Alternatif & Jumlah & Rank \\
& & $e_{k, l}=1$ & & $e_{k, l}=1$ & 24 \\
\hline 24 & A24 & 1 & A30 & 2 & 25 \\
25 & A25 & 10 & A10 & 2 & 26 \\
26 & A26 & A23 & A26 & 2 & 27 \\
27 & A27 & 10 & A21 & 1 & 28 \\
28 & A28 & 23 & A24 & 1 & 29 \\
29 & A29 & 23 & A18 & 0 & 30 \\
30 & A30 & 3 & & &
\end{tabular}

\section{KESIMPULAN}

Berdasarkan analisis yang telah dilakukan, maka diperoleh perankingan prioritas penerima beras miskin kepada masyarakat kurang mampu yang ada di Desa X. Calon penerima RASKIN pertama yang memiliki peringkat paling tinggi adalah A14 dibandingkan dengan alternatif lainnya. Kemudian diikuti secara berurutan oleh alternatif A28, A29, A22, A12, A17, A8, A6, A9, dan A13, yang berhak menerima bantuan RASKIN.

Alternatif yang masuk dalam prioritas adalah alternatif yang berada di 10 peringkat pertama. Selain dari 10 alternatif tersebut, belum bisa direkomendasikan sebagai prioritas penerima bantuan RASKIN.

\section{DAFTAR PUSTAKA}

[1]. Nainggolan, T., Merumuskan Kembali Desain Program RASKIN sebagai Program Perlindungan Sosial. Sosio Informa. 2: 91-105, 2015.

[2]. Suryeni, E., Sistem Pendukung Keputusan Kelayakan Penerimaan Bantuan Beras Miskin dengan Metode Weighted Product di Kelurahan Karikil Kecamatan Mangkubumi Kota Tasikmalaya. Proceedings Konferensi Nasional Sistem dan Informatika. 345-350, 2015.

[3]. Setiawan, F., Indriani, F., \& Aziz, M., Implementasi Metode ELECTRE Pada Sistem Pendukung Keputusan SNMPTN Jalur Undangan. Klik-Kumpulan Jurnal Ilmu Komputer. 2: 197-120, 2016.

[4]. Rogers, M. G., Bruen, M., \& Maystre, L. Y., ELECTRE and decision support: methods and applications in engineering and infrastructure investment. Springer Science \& Business Media. 2013.

[5] Dahanum, I., Mesran., Zebua, T., Sistem Pendukung Keputusan Pemilihan Internet Service Provider Menerapkan Metode Elimination and Choice Translation Reality (ELECTRE). Jurnal STMIK Budidarma. 1: 248-255, 2017.

[6]. Silalahi, A. P., Sistem Pendukung Keputusan Pemilihan Perumahan Di Kota Medan Menggunakan Metode Elimination And Choice Translation Reality (ELECTRE). Methodika: Jurnal Teknik Informatika dan Sistem Informasi. 2: 204-210, 2017.

YOSI

: Jurusan Matematika FMIPA UNTAN, Pontianak santanayossi@gmail.com

SHANTIKA MARTHA $\quad$ J Jurusan Matematika FMIPA UNTAN, Pontianak shantika.martha@math.untan.ac.id

NURFITRI IMRO'AH : Jurusan Matematika FMIPA UNTAN, Pontianak nurfitriimro'ah@math.untan.ac.id 